\title{
Social identity, personality and connectedness: probing the identity and community divides behind Brexit
}

\author{
Siobhan McAndrew, Paula Surridge and Neema Begum \\ University of Bristol
}

12 November 2017

\begin{abstract}
The UK vote to leave the European Union in June 2016 surprised and confounded academics and commentators alike. Existing accounts have focused on anti-immigration attitudes, anti-establishment sentiment and on the 'left behind', as well as national identity. This paper expands the range of possible explanations for the vote by considering a wider range of identity measures, including class and racial identities, and by considering in detail how 'connectedness' to others and to localities may have played a role in processes. We find evidence that racial identity was a factor in attitudes towards the European Union for White British voters, extending our understanding of the relationship between territorial identities, ethnicity and attitudes towards the European Union. Connectedness via networks also structures attitudes, with those with higher levels of and more diverse connections having more favourable attitudes towards the EU. Whilst these effects are smaller than those of education and age, they are nonetheless comparable with those of class and income, and suggest that we should be wary of accounts of attitudes towards the EU that fail to locate voters within their social contexts.
\end{abstract}

\section{Introduction}

The political events of 2016 surprised and confounded many commentators, and provoked some discussion of a crisis in quantitative political science and electoral studies (Jennings and Lodge 2016). Long-standing interest in political science in models based on policy positions, perceptions of competence and the fine detail of party competition and strategy, raised the question of whether there has been insufficient attention to nonpolicy information, particularly social identity and personality (for example, Jenke and Huettel 2016). Early analyses of the results and British Election Study data have demonstrated relationships between support for Brexit and social structure, most notably education (Goodwin and Heath 2016), national identity (Hobolt 2016) and social (rather than economic) values and attitudes (Kaufman 2016; Goodwin and Milazzo 2017). There has also been suggestion that 'no one factor' can explain the result (Clarke et al 2017). Thus, whilst we also reaffirm the importance of nationality and values, there remains space for other influences to have been important in shaping the outcome.

In this paper, we focus on identity, personality and relational foundations of EU referendum vote choice. In so doing, we provide an account that is explicitly grounded in political sociology. Whilst identity has been of longstanding interest in political sociology, it has featured much less in the study of electoral behaviour. Adaptation of the rational choice paradigm to incorporate identity was notably provided by Akerlof and Kranton (2000), an innovation also adopted explicitly in political science (see Jencke and Huette for an overview) but still not widespread in studies of electoral behaviour. Specifically, in relation to EU referendum voting, national identity 
has taken centre stage where identity issues have been given prominence, but other identities relating to class, ethnicity and gender, have been largely neglected.

\section{Research Context}

In their extensive analysis of referendum voting, Clarke et al suggest that the vote reflected a 'diverse mix of calculations, emotions and cues' (Clarke et al 2017: 461). Drawing on the framework set out by Hooghe and Marks (2005), which highlights 'calculation, community and cues' as the three main families of explanation for attitudes to the EU, Clarke et al demonstrate clearly the importance of calculation and cues. However, in both the original formulation and subsequent analyses, the 'community' element is narrowly conceived, focusing only on national identity as a measure of territorial attachment. This draws on a long tradition connecting attitudes to the EU with national identities; with those having stronger attachments to nations generally having less positive evaluations of the EU (Carey 2002). However, little attention is given to other sources of identity both individualised and for communities. This is curious, as the literature on attitudes to the EU identifies territorial identities more generally as important (Hooghe and Marks 2005, Carey 2002). Further, support for UKIP at the area level has been shown to be closely related to a Leave vote in the referendum (Goodwin and Heath, 2016), and in turn is connected to class and ethnic identities as well as structured by age and gender (Ford and Goodwin, 2014).

In this paper, we seek to bring together both identity and community as two aspects of 'connectedness' in the social world. As Anderson has famously argued, nations are 'imagined communities', connecting individuals together in a 'deep horizontal comradeship' (1983: 50). Other identities relate to similarly connected imagined communities, particularly those of race and class, both through shared symbols and perceptions of shared interests (for example, Kaufmann 2017 on White self-interest and racial identity). Alongside these imagined communities of shared identity, individuals are also connected to each other in 'real' communities characterised by local belonging and networks. These networks are not maintained primarily by shared symbols but by interaction between the members, with these interactions sometimes described as fostering 'social capital' among members of the networks (Putnam 2000).

Our paper is structured as follows. To provide research context, we provide a brief summary of existing research linking social identities to social attitudes, especially attitudes towards the EU. This is followed by an account of why social networks are important for political attitudes and behaviour and how network position may be associated with particular policy, vote and identificational preferences. This review informs our set of hypotheses. We then introduce our data source and modelling strategy, followed by our results. A discussion section concludes our investigation.

\section{(a) Ethnocentrism and Attitudes to the European Union}

It has long been the case that there are lower levels of 'European' identity in the UK than elsewhere in Britain (Evans 1998), and that attitudes to the European Union are related more general to national identity (Carey 2002). Within the UK, territorial identities are complex with sub-state nationalisms existing alongside British national identity. Hobolt (2016) has demonstrated the influence of English identity on Leave voting, and this is not uniform across Britain; those with stronger Scottish and Welsh identities were more likely to support Remain. This may in part reflect the different character of these national identities (Hooghe and Marks 2005). 
Those for whom multi-layered identities are the norm are more comfortable adding 'European' to the list; those for whom national identities are more exclusive are more threatened by the addition of layers of territorial identity.

There is also a long-standing literature in the UK which suggests that 'Englishness' is a racialised and exclusive identity in a way that Scottishness and Welshness are not (Bechofer and McCrone 2015; Mann and Fenton 2017). In relation to the EU, this is consistent with Duckitt's (1989) finding that ethnocentrism is associated with insecure group identification and a more civic patriotism with secure group identification, with a lower need to distance their group from outgroups. Thus, we might expect nationalisms expressly presented as 'civic', such as Scottishness, to be less likely to lead to unfavourable evaluations of the European Union.

Commitment to group identities is closely bound up with motivated reasoning, which involves a form of processing of evidence to reinforce prior identities and the political positions of those sharing our identities and worldviews (Kahan 2013). It has been suggested that motivation to vote to leave the EU related to loyalty to particular communities and worldviews. Indeed, some political figures have suggested that those campaigning to reverse the referendum decision are in some way lacking appropriate 'allegiances' (Johnson 2017). Clarke et al (2017) have indicated that supposedly 'rational' arguments failed to achieve any purchase for the remain campaign, despite consensus among public commentators that leaving the EU would be extremely costly. In relation to the cognitive and emotional aspects of vote choice, Jenke and Huettel (2017) argue that policy and identity are substitutes. Voters prefer choices where policy positions are closer to their own; but also conceive of candidates or vote choices categorically, where voting for that candidate or outcome enhances their own status within that social category. Where policy positions are highly salient, identity is less so, and vice versa.

Group affiliations, or identities, are not only about self-expression but are linked to assessments of 'other' groups and to a desire for a favourable outcome for the 'in-group' in comparison with the 'out-group'; an inherently relational judgement (Tajfel and Turner 1979). In relation to the European Union this can be seen in the desire to protect 'sovereignty' or other perceived 'in-group' benefits (quite literally in the case of 'welfare chauvinism') from erosion by members of 'out-groups' also having access to them. This is most clearly seen in the relationship between attitudes to immigration and the EU, which Goodwin and Milazzo (2017) have shown to be strongly related to referendum vote. However, they also show that anti-immigration messages resonated most strongly 'among voters who were already concerned about how migration was... producing visible changes in their local communities. This provides a critical link between our focus on identity and community more generally. In-groups and out-groups are most strongly defined by those with a sense of identity with the in-group; it is accordingly likely that those who feel more attached to their local areas may be more influenced by perceptions of threat to those areas.

\section{(b) Social Networks and Political Attitudes}

There is also a long-running social networks and interactionist tradition in political sociology, stretching back to the Columbia School of the 1940s (Lazarsfeld et al 1948). Either because of social influence and contagion, or homophily, we tend to observe that those in close contact with each other tend to think similarly. Lazer (2011) has suggested that compared with psychological and institutionalist approaches, political science has invested only 'tiny amounts' in relational accounts of political phenomena, perhaps because of the disciplinary 
lacuna between sociology (wherein social network analysis sits) and political science. The macro-level approach of Putnam (2000) however renewed interest in civic engagement and the importance of 'social capital' for effective governance.

Networks provide resources and access to information, and also serve as the social contexts in which individuals participate in social movements and form social identities (Coleman 1988). Networks both form as a result of a tendency to homophily (Vaisey and Lizardo 2010) and in turn encourage shared identities within a collective group through transmitting culture and information (Borgatti 2005), and the enforcement of shared norms. They are accordingly very likely to matter for political attitudes and behaviour, and social interaction appears particularly powerful in explaining volunteering and political participation (Wilson 2000; McClurg 2003; Brady et al 1999). Huckfeldt and Sprague's 1995 study of South Bend uncovered how network effects drive political conformity and diversity alike. A neo-Simmelian approach was also proposed by Zuckerman et al: 'the analytic language of networks, interactions, and webs of affiliation replace that of individual's voting in response to calculations of personal interests, attitudes, perceptions of the candidate or psychological attachments to political parties... voting decisions [are] reflections of the citizen's location in particular social networks' (1994: 1008-10). Such approaches focus attention further back within Hofferbert's 'funnel of causality' (1974), providing fresh engagement with the question of why social structure and basic values matter for major policy choices.

More recently, Lazer (2011) has called for greater use of ego- and whole-network analyses in political science, with recent growth in interest in political networks (especially online networks) particularly rapid (Nicoll Victor et al 2017). There is nevertheless a complementary tradition in the study of social networks whereby network position is deduced from survey items using conventional questionnaire methods (Marsden 2011), with 'position generator' type measures allowing measurement of linkage to specific social locations directly. In the British context, survey-based methods relying measures of membership of voluntary associations, friendships, and tendency to report that most people can be trusted have been used variously by sociologists and political scientists drawing on the British Household Panel Study (BHPS). Li et al have studied the effect of social support on generalised social trust, a measure of interest to sociologists, political scientists and economists alike as an indicator of 'social capital' (e.g. Putnam 2000; Putnam and Campbell 2010; Fieldhouse and Cutts 2010; Alesina and La Ferrara 2002).

Social capital may consist of different types suggesting that its dimensionality should be taken into consideration: more contacts do not necessarily mean more valuable social capital. Alesina and La Ferrara (2000) distinguish tendency to join from type of organisation. Glaeser, Laibson, and Sacerdote (2002) posit that the type of social capital in which people invest will depend on their opportunity cost of time, age, and mobility; such investment also increases with returns to social skills and area-level social capital. Owen and Videras (2009) found that individuals with high opportunity cost of time commit to types of social networks with relatively low time commitment and higher monetary cost, while those with low opportunity cost of time tend to commit to social networks with high time commitments and lower monetary cost.

Such approaches also extend to the study of network and contextual diversity. While social identity theory leads us to expect that those with strong connections to ethnocentric identities will be less positive in their attitudes towards out-groups, network diversity is often considered to increase tolerance and understanding 
of out-groups, a tradition stretching back to Allport (1954). The evidence is however mixed and contextdependent, as well as depending on the indicator of community cohesion, social trust and so on in question. It has been suggested that the positive effects of network diversity on tolerance may hold primarily for the US, though Sturgis et al have also found that social contact substantially weakens the negative association between area-level diversity and strategic trust in England; moreover, the effects of economic deprivation overwhelm those of ethnic diversity (Sturgis et al 2011). The effects of ethnically diverse networks are particularly mixed; generally negative for social cohesion in US data (Putnam 2007) while less clearly so elsewhere. Morales and Echazarra (2013) found that within-neighbourhood cohesion measured by community trust is negatively associated with ethnic heterogeneity, but that diversity appears to have no effect on generalised trust, corroborating Sturgis et al. Fieldhouse and Cutts (2010) find that diversity is negatively associated with extent of shared social norms and civic engagement, but that the positive effect of co-ethnic concentration neutralises these effects. Letki (2008) finds no negative effect of ethnic diversity on social capital once economic deprivation has been added as a control. Laurence and Bentley's (2016) analysis of the British Household Panel Study aimed to identify the causal relationship between neighbourhood diversity and attachment by examining movers and stayers: those moving to less diverse areas reported more attachment over time, while those moving to more diverse areas demonstrated little sensitivity to neighbourhood diversity. For stayers, increasing diversity was found to be associated with lower attachment.

Social networks may also foster norms regarding the acceptability of different policy choices. While the decision to vote to leave the EU was characterised by many commentators as an irrational act on economic grounds, it is plausible that network composition affected the assessment of risk. If voting for Brexit led to social approval within particular groups, it may account for a down-weighting of economic factors. Such a mechanism has been proposed to account for the decision to turn out to vote at all, less to influence the result and more 'to maintain and improve their standing in the networks and communities to which they belong' (Abrams et al 2011: 256).

\section{(c) Personality and Vote Choice}

Interest in personality effects on attitudes and vote choices has been growing in recent years (Mondak 2010), focusing on the 'Big 5 ' personality traits: agreeableness, conscientiousness, neuroticism, openness, and extraversion. McCrae describes personality in terms of tendencies: 'basic, abstract ways of living that are part of human nature, and thus found in all cultures and at all times' (McCrae 2010: 58). While not exhaustive of all individual differences, and with some scholars identifying more or fewer factors, the finding of a five-factor model of personality is quite robust, and has held in more than 50 countries (McCrae 2005; Gerber et al 2011: 266).

Personality effects on political ideology have been well-documented. Mondak et al. analysed the 2006 Congressional Elections Survey and found that openness tended to be positively associated with a range of political engagement items; conscientiousness negatively; extraversion showed some positive effects; agreeableness no significant relationships; and neuroticism negative relationships (2010: 10). While measured in their conclusions, noting that personality effects were likely mediated by factors such as political knowledge and sense of efficacy, that personality interacts with a range of attitudes, and further interact with the environment, they do highlight that this is an ambitious and important area in terms of furthering understanding of political behaviour (Mondak et al. 2010: 17-18). Gerber et al note that openness has been found to be associated with liberalism, and extraversion, neuroticism and conscientiousness with 
conservatism (2011: 269-271). The effect of agreeableness is mixed, associated with both economic liberalism and social conservatism (Gerber et al 2011: 271). Studies of partisanship are consistent with these findings, with openness generally associated with supporting liberal candidates and parties, and conscientiousness with supporting conservative candidates and parties (Gerber et al 2011: 273). Johnston et al (2017) argue that the connection between the openness trait and social dominance orientation has been consistently demonstrated, in turn connecting closely to ethnocentrism and prejudice.

It is of little surprise, then, to find that attitudes to the EU also connect with these personality measures. Bakker and De Vreese (2016), from a Dutch sample, have found that EU enlargement was associated with openness, agreeableness and neuroticism, and EU 'deepening' with neuroticism and conscientiousness. Conscientiousness was also positively associated with trust in EU institutions, and neuroticism with negative EU affect (Bakker and De Vreese 2016: 37). However, they note that despite the well-researched link between openness and 'authoritarian' values there remains a paucity of research directly connecting personality at attitude to the EU. Schoen and Schumann (2007) also note a puzzling lacuna with regard to the study of personality and foreign policy attitudes.

In including personality measures in our study, we conceive of them as another, more individualised, type of 'identity' that people may hold. Johnston et al. suggest there may be methodological issues in the measurement of these traits where 'survey participants may infer the 'proper' response to personality items based on their political identities' (2017: 232). Whilst not quite connecting to an 'imagined' community in the way that national, ethnic and class identities do, the 'Big 5' appear to express a sense of the kinds of facets people value as much as those they believe they are. Therefore, in our modelling, these measures are considered as 'individualised' identities in contrast to the group-based identities described above. We wish to establish how these may mediate structural effects, particular those of education. Education has been strongly connected to attitudes to the EU in models of structural effects (Hobolt 2016) but also to personality measures, particularly 'openness'.

\section{(d) Social Values}

There is a growing body of evidence that those who support leave in the referendum are also more likely to be 'authoritarian' in their attitudes to other issues, and that a number of issues on this dimension are strongly related at the individual level to referendum voting (Goodwin and Milazzo (2017). We are not able to address the role of values directly in this piece. In the absence of measures of immigrant resentment and measures of right-wing authoritarianism (after Adorno 1950, Altemeyer 1996) we draw instead on our identity, network and personality measures as capturing related dispositional and behavioural characteristics: identity measures partly capture what people value, and we conceive social networks as producing and adjudicating value within contexts. Schoen (2007) notes that 'deep-seated domain-specific values convey stability to specific attitudes. [In turn $t$ ] he core values at the top of the hierarchy are presumably shaped by personality characteristics, since these traits have been shown to shape an individual's worldview, to compel her to consider particular characteristics of her environment as relevant and to pursue particular goals' (2007: 410). Mische, summarising Vaisey and Lizardo (2010), has expressed it thus: 'moral worldviews provide the basis for the emotional "click" that leads to the selection of friendship relations, as well as the effort (or lack of effort) that contributes to the cultivation or decay of those ties over time' (Mische 2011: 86). We also view attitudes to the European Union themselves as a value position and in this way, we relate identity and social connectedness to this value position. It is likely that these are also connected to other value positions, and possible that effects described below may be mediated through these other values. These are not questions 
that can be addressed here. However, what can be shown is whether these identity and network effects mediate social structural effects and in turn whether there are effects of these on attitudes to the European Union, regardless of how they themselves are mediated by values.

\section{Research Questions}

Our research questions seek to broaden our understanding of how attitudes to the European Union in the UK are related to identity and networks, processes which we conceive of broadly as 'connectedness':

Which social identities are important for attitudes towards the European Union?

What is the effect of network size and diversity on attitudes towards the European Union?

Does neighbourhood attachment lead to more or less favourable attitudes towards the European Union?

How do identity, personality and social connectedness mediate the effect of social-structural variables on support for Leave versus Remain?

\section{Data and Methods}

To test our hypotheses, we draw on the 'early access' version of Wave 8 of Understanding Society, the UK Household Longitudinal Study. This comprises the first year of responses to the Wave 8 questionnaire (January 2016-December 2017); each wave is in the field for two years. While the General Population Sample was c.64000 from over 40,000 households in Wave 1 (2009-10), a combination of attrition, non-response and restriction of the Wave 8 to the first year of fieldwork means that the early access Wave 8 sample is 18,730 . Analyses are weighted to deal with non-response between Wave 2 and Wave 8. Understanding Society data are rich in measures of behaviour, identity and social locations, many of which form part of rotating modules, across a variety of social, economic and political domains. While the range of measures relevant to political science is less extensive than those on the best-known electoral studies, the quality of the sample, its innovative measures and the study's scale provide opportunities unavailable elsewhere, most notably in the ability to explore how individuals are socially connected and if that matters for political attitudes and behaviours.

Our dependent variable was included in Wave 8:

Should the United Kingdom remain a member of the European Union or leave the European Union?

Response options comprised 'Remain a member of the European Union', and 'Leave the European Union'. The meaning of the question clearly altered before and after 23 June 2016; and it is not an indicator of intended or reported referendum vote choice. Nevertheless, it has value in reflecting attitudes towards the European Union which we can treat as a proxy for how the respondent voted in June 2016. In our sample, 45.2 per cent indicated support for leaving the EU, and 54.8 per cent for remaining in the EU - a percentage slightly below that for the eventual Leave result of 51.9 per cent, which may be due to attitudes changing over the course of the referendum campaign, perhaps due to issues with the sample itself, which both includes those who were 
not eligible/registered to vote in the referendum and is likely to have experienced some non-random attrition over time.

Using logit models, we code as 1 support for leaving the European Union and 0 support for remaining in the European Union. We begin with a social-structural model, including social generation (pre-war, Baby Boom, Generation X, Generation Y); self-reported ethnicity; education (graduate status versus not having a university degree); class using the NS-SEC measure of occupational status; household income included in quintile groups; housing tenure (social renters, private renters, owner-occupiers and mortgage-holders); and a measure of whether the respondent was based in Scotland or not. Note that class was coded from the most recent wave for which an occupation was reported; where no NS-SEC category was available (for example, for those consistently retired or homemakers over Waves 1-6), employment status was taken from Wave 6. Descriptive statistics are reported in Table A1 in the Appendix. We report breakdowns by support for leaving the EU versus remaining in Tables 1 and 2 below, the first for the 'structural' variables and the second for the variables we conceive as possible mediators.

\begin{tabular}{|c|c|c|}
\hline & $\begin{array}{l}\text { Percentage supporting } \\
\text { Leave (\%) }\end{array}$ & Test of independence \\
\hline Male & 46.8 & $X^{2}(1, N=17,088)=39.18$ \\
\hline Female & 43.7 & $p<0.001$ \\
\hline Pre-war & 55.8 & $X^{2}(3, N=17,888)=312.55$ \\
\hline Baby Boom & 49.7 & $p<0.001$ \\
\hline Generation X & 42.3 & \\
\hline Generation $Y$ & 34.5 & \\
\hline White British & 47.5 & $X^{2}(5, N=16,805)=377.79$ \\
\hline White Other & 24.8 & $p<0.001$ \\
\hline Mixed & 20.1 & \\
\hline Asian & 34.2 & \\
\hline Black & 24.8 & \\
\hline Other ethnic group & 32.2 & \\
\hline Has a degree & 24.2 & $X^{2}(1, N=17,840)=931.00$ \\
\hline Does not have a degree & 42.0 & $p<0.001$ \\
\hline $\begin{array}{l}\text { NS-SEC } 1 \text { (Managerial and } \\
\text { Professional) }\end{array}$ & 34.0 & $\begin{array}{l}X^{2}(7, N=17,780)=646.70 \\
p<0.001\end{array}$ \\
\hline NS-SEC 2 (Intermediate) & 46.6 & \\
\hline NS-SEC 3 (Small Business & 53.6 & \\
\hline Employers, Self-Employed) & & \\
\hline $\begin{array}{l}\text { NS-SEC } 4 \text { (Lower Supervisory, } \\
\text { Semi-Routine) }\end{array}$ & 52.3 & \\
\hline NS-SEC 5 (Routine) & 56.7 & \\
\hline Retired & 53.6 & \\
\hline Student & 27.1 & \\
\hline Other (outside labour market) & 50.6 & \\
\hline Income quintile group I & 53.2 & $X^{2}(4, N=16,919)=425.66$ \\
\hline Income quintile group 2 & 53.5 & $p<0.001$ \\
\hline Income quintile group 3 & 49.0 & \\
\hline Income quintile group 4 & 43.1 & \\
\hline Income quintile group 5 & 33.1 & \\
\hline Owner-occupier & 48.3 & $X^{2}(3, N=16,895)=235.35$ \\
\hline
\end{tabular}




\begin{tabular}{lll} 
Mortgage holder & 38.7 & $p<0.001$ \\
Social renter & 57.1 & \\
Private renter & 40.9 & $X^{2}(1, N=16,919)=157.05$, \\
\hline Resident in Scotland & 29.6 & $p<0.001$ \\
Not resident in Scotland & 46.7 & \\
\hline
\end{tabular}

Table 1: Support for leaving the EU by social-structural variables. Understanding Society and authors' analysis. Wave 8 weights used to adjust for non-response; unweighted $\mathrm{N}$ reported.

\begin{tabular}{|c|c|c|c|}
\hline Item & Response option/group & $\begin{array}{l}\text { Percentage } \\
\text { supporting } \\
\text { Leave (\%) or } \\
\text { average scores for } \\
\text { Leave/Remain } \\
\text { supporters }\end{array}$ & $\begin{array}{l}\text { Test of independence } \\
\text { across/ } \\
\text { difference between } \\
\text { groups }\end{array}$ \\
\hline \multirow{2}{*}{$\begin{array}{l}\text { Age important to who } \\
\text { you are }\end{array}$} & Very/fairly & 44.5 & $X^{2}(1, N=17,844)=$ \\
\hline & Not very/not at all & 46.6 & $21.58, p<0.001$ \\
\hline \multirow{2}{*}{$\begin{array}{l}\text { Gender important to } \\
\text { you who are }\end{array}$} & Very/fairly & 46.1 & $X^{2}(1, N=17,841)=$ \\
\hline & Not very/not at all & 43.5 & $0.93, p=0.335$ \\
\hline \multirow{2}{*}{$\begin{array}{l}\text { Family important to } \\
\text { you who are }\end{array}$} & Very/fairly & 45.2 & $X^{2}(1, N=17,856)=$ \\
\hline & Not very/not at all & 45.0 & $2.95, p=0.086$ \\
\hline \multirow{2}{*}{$\begin{array}{l}\text { Ethnicity important to } \\
\text { you who are }\end{array}$} & Very/fairly & 47.1 & $X^{2}(1, N=17,836)=$ \\
\hline & Not very/not at all & 43.8 & $4.65, p=0.031$ \\
\hline \multirow{2}{*}{$\begin{array}{l}\text { Education important } \\
\text { to you who are }\end{array}$} & Very/fairly & 40.4 & $X^{2}(1, N=17,844)=$ \\
\hline & Not very/not at all & 53.4 & $306.03, p<0.001$ \\
\hline \multirow{2}{*}{$\begin{array}{l}\text { Profession important } \\
\text { to you who are }\end{array}$} & Very/fairly & 40.1 & $X^{2}(1, N=17,896)=$ \\
\hline & Not very/not at all & 52.5 & $292.80, p<0.001$ \\
\hline \multirow{2}{*}{$\begin{array}{l}\text { Politics important to } \\
\text { you who are }\end{array}$} & Very/fairly & 40.8 & $X^{2}(1, N=17,833)=$ \\
\hline & Not very/not at all & 47.8 & $65.36, p<0.001$ \\
\hline \multirow[t]{2}{*}{ Britishness important } & Score 6-10 & 49.4 & $X^{2}(1, N=16,323)=$ \\
\hline & Score 0-5 & 32.4 & $395.84, p<0.001$ \\
\hline \multirow[t]{2}{*}{ Neuroticism } & Leave & 3.53 & $t(14,280)=-2.48$ \\
\hline & Remain & 3.61 & $p=0.013$ \\
\hline \multirow[t]{2}{*}{ Agreeableness } & Leave & 5.63 & $t(14,281)=3.55$ \\
\hline & Remain & 5.55 & $p<0.001$ \\
\hline \multirow[t]{2}{*}{ Openness } & Leave & 4.42 & $t(14,253)=-10.71$ \\
\hline & Remain & 4.70 & $p<0.001$ \\
\hline \multirow[t]{2}{*}{ Conscientiousness } & Leave & 5.49 & $t(14,285)=4.04$ \\
\hline & Remain & 5.39 & $p<0.001$ \\
\hline \multirow[t]{2}{*}{ Extraversion } & Leave & 4.58 & $t(14,287)=1.51$ \\
\hline & Remain & 4.54 & $p=0.131$ \\
\hline \multicolumn{2}{|l|}{ No religious affiliation } & 46.0 & $X^{2}(5, N=15,827)=$ \\
\hline \multicolumn{2}{|l|}{ Anglican } & 52.5 & $190.13, p<0.001$ \\
\hline \multicolumn{2}{|l|}{ Catholic } & 39.6 & \\
\hline \multicolumn{2}{|l|}{ Other Christian } & 40.3 & \\
\hline \multicolumn{2}{|l|}{ Other religion } & 35.2 & \\
\hline $\begin{array}{l}\text { Respondent indicates } \\
\text { has religious } \\
\text { affiliation, not coded }\end{array}$ & & 35.2 & \\
\hline
\end{tabular}




\begin{tabular}{|c|c|c|c|}
\hline $\begin{array}{l}\text { Attends a place of } \\
\text { worship at least } \\
\text { weekly } \\
\text { Attends less } \\
\text { frequently }\end{array}$ & & 46.7 & $\begin{array}{l}X^{2}(2, N=15,824)= \\
87.16, p<0.001\end{array}$ \\
\hline Never attends & & 47.9 & \\
\hline $\begin{array}{l}\text { Friends are of similar } \\
\text { age }\end{array}$ & $\begin{array}{l}\text { More than half } \\
\text { Half or less }\end{array}$ & $\begin{array}{l}43.4 \\
48.9\end{array}$ & $\begin{array}{l}X^{2}(1, N=16,417)= \\
43.33, p<0.001\end{array}$ \\
\hline $\begin{array}{l}\text { Friends are of same } \\
\text { race }\end{array}$ & $\begin{array}{l}\text { More than half } \\
\text { Half or less }\end{array}$ & $\begin{array}{l}45.5 \\
41.4\end{array}$ & $\begin{array}{l}X^{2}(1, N=16,414)= \\
21.15, p<0.001\end{array}$ \\
\hline $\begin{array}{l}\text { Friends are of similar } \\
\text { level of education }\end{array}$ & $\begin{array}{l}\text { More than half } \\
\text { Half or less }\end{array}$ & $\begin{array}{l}44.5 \\
45.1\end{array}$ & $\begin{array}{l}X^{2}(1, N=15,985)= \\
1.45, p=0.228\end{array}$ \\
\hline Friends have a job & $\begin{array}{l}\text { More than half } \\
\text { Half or less }\end{array}$ & $\begin{array}{l}42.3 \\
49.5\end{array}$ & $\begin{array}{l}X^{2}(1, N=16,342)= \\
67.36, p<0.001\end{array}$ \\
\hline $\begin{array}{l}\text { Friends have similar } \\
\text { income }\end{array}$ & $\begin{array}{l}\text { More than half } \\
\text { Half or less }\end{array}$ & $\begin{array}{l}44.9 \\
43.1\end{array}$ & $\begin{array}{l}X^{2}(1, N=13,310)= \\
0.86, p=0.355\end{array}$ \\
\hline $\begin{array}{l}\text { Friends living in same } \\
\text { local area }\end{array}$ & $\begin{array}{l}\text { More than half } \\
\text { Half or less }\end{array}$ & $\begin{array}{l}48.4 \\
42.4\end{array}$ & $\begin{array}{l}X^{2}(1, N=15,340)= \\
49.60, p<0.001\end{array}$ \\
\hline $\begin{array}{l}\text { Friends also family } \\
\text { members }\end{array}$ & $\begin{array}{l}\text { More than half } \\
\text { Half or less }\end{array}$ & $\begin{array}{l}51.0 \\
44.0\end{array}$ & $\begin{array}{l}X^{2}(1, N=12,557)= \\
27.05, p<0.001\end{array}$ \\
\hline $\begin{array}{l}\text { Average number of } \\
\text { close friends }\end{array}$ & $\begin{array}{l}\text { Leave } \\
\text { Remain }\end{array}$ & $\begin{array}{l}5.4 \\
5.3\end{array}$ & $\begin{array}{l}t(16,470)=0.45 \\
p=0.652\end{array}$ \\
\hline Civic organisation & $\begin{array}{l}\text { Member } \\
\text { Not a member }\end{array}$ & $\begin{array}{l}41.2 \\
50.5\end{array}$ & $\begin{array}{l}X^{2}(1, N=17,507)= \\
119.40, p<0.001\end{array}$ \\
\hline $\begin{array}{l}\text { Belongs to } \\
\text { neighbourhood }\end{array}$ & $\begin{array}{l}\text { Agree } \\
\text { Does not agree or } \\
\text { neither agree/disagree }\end{array}$ & $\begin{array}{l}44.6 \\
45.7\end{array}$ & $\begin{array}{l}X^{2}(1, N=16,346)= \\
7.05, p=0.008\end{array}$ \\
\hline $\begin{array}{l}\text { Local friends mean a } \\
\text { lot }\end{array}$ & $\begin{array}{l}\text { Agree } \\
\text { Does not agree or } \\
\text { neither agree/disagree }\end{array}$ & $\begin{array}{l}45.7 \\
43.8\end{array}$ & $\begin{array}{l}X^{2}(1, N=16,346)= \\
0.21, p=0.644\end{array}$ \\
\hline $\begin{array}{l}\text { Advice obtainable } \\
\text { locally }\end{array}$ & $\begin{array}{l}\text { Agree } \\
\text { Does not agree or } \\
\text { neither agree/disagree }\end{array}$ & $\begin{array}{l}46.2 \\
43.3\end{array}$ & $\begin{array}{l}X^{2}(1, N=16,341)= \\
2.64, p=0.10\end{array}$ \\
\hline $\begin{array}{l}\text { Can borrow things } \\
\text { from neighbours }\end{array}$ & $\begin{array}{l}\text { Agree } \\
\text { Does not agree or } \\
\text { neither agree/disagree }\end{array}$ & $\begin{array}{l}43.5 \\
46.0\end{array}$ & $\begin{array}{l}X^{2}(1, N=16,335)= \\
14.36, p<0.001\end{array}$ \\
\hline $\begin{array}{l}\text { Willing to improve } \\
\text { neighbourhood }\end{array}$ & $\begin{array}{l}\text { Agree } \\
\text { Does not agree or } \\
\text { neither agree/disagree }\end{array}$ & $\begin{array}{l}42.8 \\
50.1\end{array}$ & $\begin{array}{l}X^{2}(1, N=16,335)= \\
72.04, p<0.001\end{array}$ \\
\hline $\begin{array}{l}\text { Plan to stay in } \\
\text { neighbourhood }\end{array}$ & $\begin{array}{l}\text { Agree } \\
\text { Does not agree or } \\
\text { neither agree/disagree }\end{array}$ & $\begin{array}{l}45.8 \\
42.7\end{array}$ & $\begin{array}{l}X^{2}(1, N=16,343)= \\
2.11, p=0.146\end{array}$ \\
\hline $\begin{array}{l}\text { Am similar to others in } \\
\text { neighbourhood }\end{array}$ & Agree & $\begin{array}{l}47.0 \\
41.2\end{array}$ & $\begin{array}{l}X^{2}(1, N=16,337)= \\
20.29, p<0.001\end{array}$ \\
\hline
\end{tabular}




\begin{tabular}{|c|c|c|c|}
\hline & $\begin{array}{l}\text { Does not agree or } \\
\text { neither agree/disagree }\end{array}$ & & \\
\hline Talk regularly to & Agree & 46.4 & $X^{2}(1, N=16,336)=$ \\
\hline neighbours & $\begin{array}{l}\text { Does not agree or } \\
\text { neither agree/disagree }\end{array}$ & 41.6 & $14.05, p<0.000$ \\
\hline
\end{tabular}

Table 2. Support for leaving the EU by intervening variables. Understanding Society and authors' analysis. Wave 8 weights used to adjust for non-response; unweighted $\mathrm{N}$ reported.

We then report the results of our nested nonlinear probability models, examining the extent to which the structural variables are mediated by those variables we conceive as intervening: social identity, personality, and measures of social connectedness and network diversity. These mediating variables were measured as follows.

\section{(a) Social identity variables}

Our main set of identity measures are taken from the self-completion element of Wave 8 of the data. Respondents were asked:

'We'd like to know how important various things are to your sense of who you are. Please think about each of the following your...

Age and life stage; gender; ethnic or racial background; profession; education; family; political beliefs

Response options comprised 'very important to my sense of who I am; fairly important; not very important; not at all important'. The measures are dichotomised so that for each potential identity the respondent received a score of 1 if they indicated it was very or fairly important to their sense of self and 0 otherwise. Since national identity was not covered in this battery, we used a measure drawn from Wave 6, where national identity was measured using an 11-point scale of 'Britishness'. Respondents were asked to indicate how important being British is to them, on a scale of 0 to 10 where 0 means 'not at all important' and 10 means 'extremely important'. We dichotomised this at 6 , so that those giving a score of 0-5 were judged to consider being British not important or only moderately so; and those giving a score of 6 and above considering it quite or very important.

We also take account of religious affiliation and practice, noting that religiosity has both identity-related and behavioural dimensions. First, we consider the respondent's religious affiliation, contrasting members of particular denominations with those who report none. Secondly, we take account of active religious practice, comparing those who attend a place of worship at least weekly and those who attend less frequently with those who never attend. It is well-established that nominal Christianity, particularly nominal Anglicanism, is associated with 'Christian nationalism' and more negative attitudes towards outgroups while active religious practice tends to be pro-social. We also note that active religious practice overlaps heavily with social capital (Saguaro Seminar cited in Dilulio 2007: 155) and is worthy of inclusion as an additional indicator of connectedness. We are agnostic regarding the direction of effects; cues from religious leaders tended to be muted and mixed during the EU Referendum campaign, and active practice is often in the context of less diverse religious communities (Putnam and Sanders 2010; Storm 2015). 


\section{(b) Personality variables}

Psychologists tend to use a large battery of items to measure personality: the Revised NEO PI-R consists of 240 items, with both self-report and observer versions, while a shorter NEO-FFI (NEO Five-Factor Inventory) comprises 60 , or 12 per factor. The items included in Wave 3 of Understanding Society are a little thinner, and it is less self-evident that they map closely onto personality traits; however, they could be conceived as capturing identification with particular attributes which the respondent may value. Accordingly, we treat these variables as being rather closer to the social identity measures than might be thought at first glance. Respondents were asked to rate how they perceive themselves against a 15 -item personality inventory. Each personality dimension is represented by the answers to three questions that are reported on a scale ranging from 1 (does not apply to me at all) to 7 (applies to me perfectly):

I see myself as someone who:

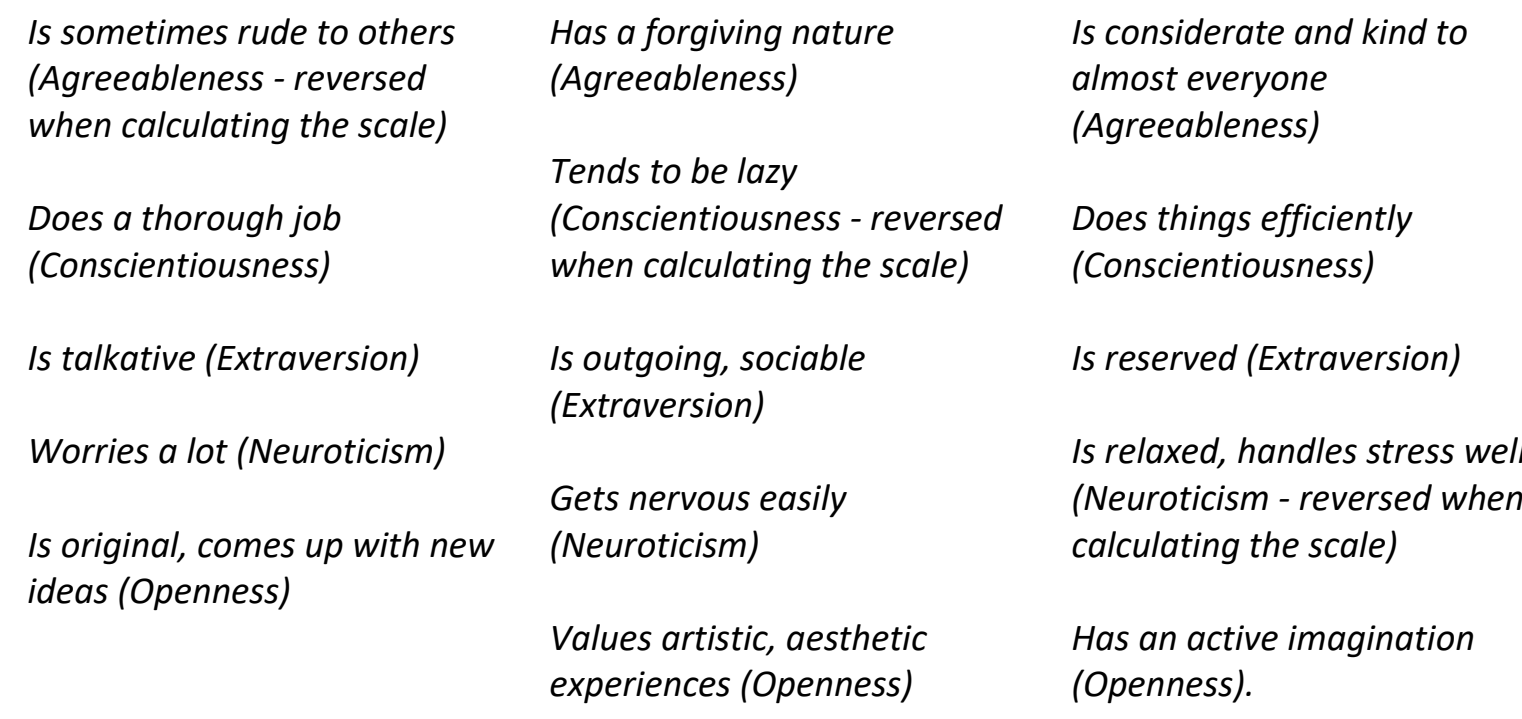

We calculate the mean for each trait, with the minimum possible being 1 and the maximum 7 .

\section{(c) Social network variables}

There is a rich array of associational and network-related variables in the data, particularly in waves 3 and 6 , and we identified 31 measures as of being particular interest. These cover measures of friendship diversity and a self-reported number of close friendships; measures of associational memberships and of active involvement in the relevant organisations; and measures of neighbourhood attachment. Regarding friendship diversity, respondents were asked the proportion of their friends of a similar age, of the same race, of a similar level of education, who are in employment, who have a similar income, who live in the same local area, and who are also family members. Responses were on a four-point scale: all, more than half, about half, less than half. The reported number of close friends ranged from 0 to 500 .

Respondents were also asked whether they were a member of a range of associations, as well as whether they were an active member (we leave the latter indicator aside in the current paper). This selection comprised the 
following: trade unions, environmental groups, parents'/school associations, tenants'/residents' group or Neighbourhood Watch, religious group or church organisation, voluntary services group, pensioners' group/organisation, Scouts/Guides organisation, professional organisation, other community or civic group, social club/working men's club, sports club, Women's Institute/Townswomen's Guild, women's group/feminist organisation, or other. For this paper, we created a simple binary measure of whether the respondent were a member of at least one association. In future work it will be possible to identify volume of memberships as well as extent of involvement; but this simple measure preserved some variation across respondents while capturing a straightforward divide between joiners and non-joiners. Regarding neighbourhood attachment, respondents were asked their level of agreement with the following statements:

I feel like I belong to this neighbourhood.

The friendships and associations I have with other people in my neighbourhood mean a lot to me.

If I needed advice about something I could go to someone in my neighbourhood.

I borrow things and exchange favours with my neighbours.
I would be willing to work together with others on something to improve my neighbourhood. I plan to remain a resident of this neighbourhood for a number of years.

I think of myself as similar to the people that live in this neighbourhood.

I regularly stop and talk with people in my neighbourhood.

Responses were available on a five-point scale, ranging from 'strongly disagree' to 'strongly agree'. A similar battery was employed by Laurence and Bentley (2016) to validate their choice of dependent variable; they interpreted them as relating to a dimension of local attachment or sense of neighbourhood belonging rather than community cohesion, and we conceive of them similarly here.

\section{(d) Measurement and Modelling Strategy}

Having explored the data, we proceeded to reduce the large number of variables to a more manageable set. A key issue was to create a social network typology using the items relating to diversity and volume of friendships. We conducted latent class analysis to identify structure in the data. Table A2 in the Appendix illustrates a range of fit statistics for different solutions, from 2 to 8 . While the entropy scores are admittedly low, its increase slows markedly from the three-class solution onwards, and so we chose the three-class solution. How these are associated with the manifest variables is summarised in Table A3 below, and with a range of demographic variables and with Leave support in Table A4. Despite the fuzziness of the classes, the differences in probability of class membership for each of the manifest variables are reasonably clear, allowing us to characterise the classes as follows. Class 1 can be interpreted as comprising low volume, and low diversity; class 2 higher volume, and moderate diversity; and class 3 low volume, high diversity. Ethnic diversity appears highest for members of class 3 . Class 2 is the more clearly advantaged with the highest proportion of graduates and the lowest proportion of members in the lowest income quintile group. Members of this class also have more close friends on average. Members of class 1 exhibit the highest levels of age-related, ethnic, income-related and educational homophily, and the lowest number of close friends on average. This group appears closest to the archetype described by some of the commentariat as bonded and traditional; the oldest generation is highly-represented here. Further, the highest rate of support for leaving the EU is shown by members of class 2 . 
We also create a measure of neighbourhood attachment by conducting common factor analysis of the eight neighbourhood attachment variables above. A single factor was retained, explaining $48 \%$ of the variance. The precise loadings are reporting in Table A5 of the Appendix; all were above 0.5 . While the factorial structure appears well-identified, we are more circumspect regarding the claims of the three-factor solution to high definition with low heterogeneity within the classes and high heterogeneity between them; ideally the entropy score would be well above 0.9. Nevertheless, we include class membership as an intervening variable in the interest of including a more parsimonious representation of community heterogeneity than provided by including each variable separately. We also note that Van der Eijk and Marsh (2009) adopted a similar twostep modelling approach fruitfully to examine drivers of the Irish Lisbon vote taking voter heterogeneity explicitly into account; in that case, four latent classes of Irish voter were identified on the basis of manifest variables covering EU attitudes, Irish identification, and attitudes towards the Lisbon treaty.

\section{Discussion}

Following exploratory analysis, we first fit a social-structural model followed by a full model of support for leaving the European Union. Because our models are nested, we would usually aim to interpret the changes in coefficients with the addition of the variables we conceive as intervening. Because our model is nonlinear, the comparison of coefficients is not straightforward, since coefficients partly depend on scaling effects due to heterogeneity (Best and Wolf 2015; Karlson et al 2011). For the comparison between models we use the correction recommended by Karlson et al, comparing coefficients for the same set of cases and correcting for rescaling which would otherwise occur between the reduced and full models. This allows us to compare coefficients meaningfully, and compare the explanatory power of structural mechanisms from those which are relational-identificational.

\begin{tabular}{|c|c|c|c|c|c|}
\hline & \multicolumn{2}{|c|}{ Restricted model } & \multicolumn{2}{|l|}{ Full model } & \multirow{2}{*}{$\begin{array}{l}\text { Average marginal } \\
\text { effects (full model) }\end{array}$} \\
\hline & Coefficient & $p$-value & Coefficient & $p$-value & \\
\hline Constant & -0.212 & 0.105 & 0.104 & 0.711 & - \\
\hline Male vs female & 0.190 & $<0.001$ & 0.212 & $<0.001$ & 0.045 \\
\hline $\begin{array}{l}\text { Holds degree vs no } \\
\text { degree }\end{array}$ & -0.898 & $<0.001$ & -0.737 & $<0.001$ & -0.158 \\
\hline \multicolumn{6}{|l|}{$\begin{array}{l}\text { Base: Baby Boom } \\
\text { generation }\end{array}$} \\
\hline Pre-war generation & 0.123 & 0.111 & 0.081 & 0.302 & 0.017 \\
\hline Generation X & -0.149 & 0.034 & -0.143 & 0.045 & -0.031 \\
\hline Generation $Y$ & -0.532 & $<0.001$ & -0.452 & $<0.001$ & -0.097 \\
\hline \multicolumn{6}{|c|}{$\begin{array}{l}\text { Base: Professional or } \\
\text { managerial occupation }\end{array}$} \\
\hline $\begin{array}{l}\text { Intermediate } \\
\text { occupation }\end{array}$ & 0.289 & $<0.001$ & 0.248 & 0.003 & 0.054 \\
\hline
\end{tabular}




\begin{tabular}{|c|c|c|c|c|c|}
\hline $\begin{array}{l}\text { Self-employed, small } \\
\text { business owners }\end{array}$ & 0.402 & $<0.001$ & 0.349 & $<0.001$ & 0.076 \\
\hline $\begin{array}{l}\text { Semi-routine } \\
\text { occupation }\end{array}$ & 0.416 & $<0.001$ & 0.343 & $<0.001$ & 0.074 \\
\hline Routine occupation & 0.489 & $<0.001$ & 0.380 & $<0.001$ & 0.082 \\
\hline Retired (all waves) & 0.224 & 0.024 & 0.144 & 0.150 & 0.031 \\
\hline Student & 0.390 & 0.323 & 0.346 & 0.380 & 0.075 \\
\hline $\begin{array}{l}\text { Other (outside labour } \\
\text { market) }\end{array}$ & 0.329 & 0.062 & 0.299 & 0.091 & 0.065 \\
\hline \multicolumn{6}{|l|}{ Base: White British } \\
\hline White Other & -0.913 & $<0.001$ & -0.689 & $<0.001$ & -0.145 \\
\hline Mixed ethnicity & -1.266 & $<0.001$ & -1.246 & $<0.001$ & -0.245 \\
\hline Asian & 0.099 & 0.627 & 0.038 & 0.856 & 0.008 \\
\hline Black & -1.204 & $<0.001$ & -1.227 & $<0.001$ & -0.243 \\
\hline Other ethnicity & -0.179 & 0.749 & -0.179 & 0.750 & -0.039 \\
\hline \multicolumn{6}{|l|}{$\begin{array}{l}\text { Base: Occupier with } \\
\text { mortgage }\end{array}$} \\
\hline Owner-occupier & -0.023 & 0.742 & -0.045 & 0.520 & -0.010 \\
\hline Social renter & 0.314 & 0.001 & 0.269 & 0.005 & 0.058 \\
\hline Private renter & 0.045 & 0.651 & 0.043 & 0.667 & 0.010 \\
\hline \multicolumn{6}{|l|}{$\begin{array}{l}\text { Base: No religious } \\
\text { affiliation }\end{array}$} \\
\hline Anglican & 0.084 & 0.200 & 0.028 & 0.676 & 0.006 \\
\hline Catholic & -0.006 & 0.955 & -0.022 & 0.837 & -0.005 \\
\hline Other Christian & 0.038 & 0.677 & 0.009 & 0.922 & 0.003 \\
\hline Other Religion & -0.374 & 0.033 & -0.410 & 0.020 & -0.087 \\
\hline $\begin{array}{l}\text { Reports having religious } \\
\text { affiliation but coded } \\
\text { 'inapplicable' }\end{array}$ & -0.317 & 0.004 & -0.243 & 0.030 & -0.052 \\
\hline \multicolumn{6}{|l|}{$\begin{array}{l}\text { Base: Never attends a } \\
\text { place of worship }\end{array}$} \\
\hline $\begin{array}{l}\text { Attends a place of } \\
\text { worship less frequently }\end{array}$ & 0.273 & 0.002 & 0.203 & 0.022 & 0.043 \\
\hline Attends at least weekly & 0.390 & $<0.001$ & 0.309 & 0.003 & 0.066 \\
\hline
\end{tabular}


Base: Middle income

\section{quintile group}

Lowest income quintile

$-0.001$

0.988

$-0.009$

0.918

$-0.002$

group

Second income quintile

0.039

0.631

0.023

0.778

0.004

group

Fourth income quintile $\quad-0.12$

$0.122 \quad 0.117$

$-0.141$

0.072

$-0.031$

group

Highest income quintile

$-0.327$

$<0.001$

$-0.341$

$<0.001$

$-0.074$

group

Base: resident in

England and Wales

Resident in Scotland

$-0.982$

$<0.001$

$-0.862$

$<0.001$

$-0.185$

Base: Not very/not at all

important in each case

Race/ethnicity very/fairly important Profession very/fairly important

Education very/fairly

important

Age very/fairly

important

Politics very/fairly

important

Gender very/fairly

important

Family very/fairly

important

Britishness important

(scores $6+$ out of 10 vs.

0-5)

Big 5 personality

variables

Neuroticism

\begin{tabular}{ll}
0.227 & $<0.001$ \\
-0.142 & 0.023 \\
-0.082 & 0.209 \\
-0.095 & 0.156 \\
-0.344 & $<0.001$ \\
0.108 & 0.098 \\
0.006 & 0.959 \\
0.554 & $<0.001$ \\
\hline
\end{tabular}

0.048

$-0.030$

$-0.017$

$-0.020$

$-0.074$

0.023

0.001

Agreeableness

$-0.013$

0.523

$-0.003$

Agreeableness
Openness
Conscientiousness
Extraversion

$\begin{array}{ll}-0.160 & <0.001 \\ -0.060 & 0.009 \\ 0.115 & <0.001 \\ 0.057 & 0.009\end{array}$

$-0.034$

$-0.013$

0.024

0.012

Base: low volume, low

diversity network

High volume, moderate

diversity

Low volume, high

$\begin{array}{ll}-0.207 & 0.001 \\ -0.029 & 0.687\end{array}$

$-0.044$

$-0.006$ 


\begin{tabular}{|c|c|c|c|c|}
\hline $\begin{array}{l}\text { Member of a civic } \\
\text { organisation vs not } \\
\text { member } \\
\text { Neighbourhood } \\
\text { attachment }\end{array}$ & & -0.122 & 0.029 & -0.011 \\
\hline Pseudo $R^{2}$ & 0.109 & 0.109 & & \\
\hline$N$ & 10,968 & 10,968 & & \\
\hline
\end{tabular}

Table 3: Results of social-structural (reduced) and identificational-relational models of support for leaving the European Union, with KHB correction and robust standard errors. Wave 8 weights applied; unweighted $\mathrm{N}$ reported. Unweighted Source: Understanding Society and authors' analysis.

The structural model indicates that being male rather than female is associated with greater support for leaving the EU. Having a degree rather than no degree is associated with a large effect on support for remaining within the EU. Of the social generational terms, being a member of the pre-war generation rather than a Baby Boomer is associated with greater support for leaving the EU, although difference is shy of statistical significance. Being a member of Generation $\mathrm{X}$ or $\mathrm{Y}$ rather than a Boomer is associated with stronger support for Remain. We also observe variation in support by occupational status, controlling for third factors. Compared with professional and managerial workers, small business owners, intermediate workers, and semiroutine and routine workers are all more supportive of leaving the EU. The retired (not otherwise distinguished by occupation) are more supportive of leaving the EU than professional and managerial workers; those identified as students are not. Those outside the labour market (home-makers, the sick and disabled and never-worked) are apparently more supportive of leaving the EU (although again $0.1<p<0.05$ ). Of the race and ethnicity terms, being White Other (capturing EU and Irish citizens resident in Britain) rather than White British has a large and highly significant effect on supporting remaining in the EU rather than leaving. Being of mixed ethnicity or Black (British and other) rather than White British also has a large effect on supporting remaining with the EU. Being Asian or of another ethnicity rather than White British is associated with no significant difference in terms of support for leaving or remaining.

The social-structural model also includes terms for housing tenure, of interest given the racialisation of discourse regarding social housing, for example in Barking and Dagenham in the late 2000s (Harris 2010). Moreover, access to social housing has been 'one of the most frequently cited injustices of new immigration in Britain', diagnosed by some as a moral panic (Robinson 2010). We find that compared with owner-occupiers, neither mortgaged occupiers nor private renters were more likely to support leaving the EU. However, social renters were significantly more likely to do so. In terms of religious affiliation, we find, perhaps surprisingly, that being Anglican, Catholic or other Christian rather than of no religion (controlling for third factors, including attendance at a place of worship) has no significant effect on support for leaving the EU. Given findings that 'Christian nationalism' is associated with attitudes to immigration, and religious affiliation with EU attitudes, this is of interest (Storm 2011). However, being an adherent of a religion other than Christianity, or having identified as having a religious affiliation which was coded by Understanding Society as 'inapplicable' (which we suspect may include Jedi Knights, Pastafarians and so forth) is associated with significantly stronger support for remaining in the EU. There may well be some collinearity with immigrant heritage or social generation in those cases. We also find that active religiosity via more frequent attendance at a place of worship is significantly associated with lower support for leaving the EU. While both the Brexit and Trump phenomena have been discussed in terms of 'cultural backlash' (Inglehart and Norris 2016), in this instance the effects of 
a particular example of cultural practice (in the form of active religiosity) has differential effects depending on the context, perhaps because religion is mainstream in the US but counter- or sub-cultural in Britain.

We now turn to the effects of income, partly to test the effect of 'left-behind' status. While a continuous measure of income yielded a significant negative result on support for leaving the EU (results not shown), we chose to divide the household income measure into five quintile groups. Comparing each group to the middle income group, we see no significant differences except for the highest income quintile group, which is significantly more supportive of remaining in the EU. This is not strongly consistent with a materialist story in that the difference in attitudes is clearest for the most advantaged in income terms only. We also originally included a set of regional dummies (not shown), but given the lack of significant differences across regions except for that between Scotland and the rest, in the interests of parsimony we included only a term for whether the respondent were resident in Scotland. Consistent with what is well-known, this was associated with stronger support for remaining in the EU.

Finally, we fit the full model, including our full set of personality, identity-related and connectedness measures. What is clear is that very few of the social-structural variables are affected to any great degree by the addition of the variables we conceive of as intervening variables. In other words, their effect is not greatly affected by the additional variables, so that at first glance it seems unlikely that they should be considered as either confounders or mediators of the social-structural variables. Given the prominence of the social capital literature in both political science and sociology, and the role social networks play in stratification (Pichler and Wallace 2009), and the interest devoted to the Brexit result as a 'cultural' (in other words, identity-related) phenomenon, this is of interest.

When examining the difference between the direct and total effects (direct plus indirect) of each socialstructural variable on support for leaving the EU (not shown), in no case was the difference statistically significant, suggesting that the direct effects dominate the indirect effects. Further, few of the social-structural items change significance in Table 3 with the addition of the identificational and connectedness measures, save that for being retired rather than professional/managerial (which loses significance) and that for being a member of the fourth income quintile group rather than third (which moves from insignificant to positive and significant, albeit $0.1<p<0.05$ ).

Of the identity and relational variables, we see that the inclusion of the measure of whether race or ethnicity is fairly or very important to who you are predicts greater support for leaving the EU. In further analysis (not shown) this is particularly true of the White British. When conducting the analysis separately for the White British and ethnic minority respondents, we find that the measure of race or ethnicity being important to who you are has no significant effect for members of the other ethnic groups. Having a stronger professional identity is associated with greater support for remaining in the EU, beyond the effect of occupational status. Having a stronger identity with regard to age and education is associated with greater support for remaining in the EU; having a stronger identity with regard to gender with leaving the EU, albeit at only the 10 per cent level of significance. Reporting that family is very or fairly important to who you are (as the vast majority of respondents do) has no association with support for leaving the EU. 
Of particular interest given the finding regarding racial identity is that for Britishness. Having a stronger Britishness identity (giving a score of 6 or more out of 10 on the question of 'how important is being British to you?') is associated with a large and positive effect on support for leaving the EU. Notably, this holds for the White British and those other than White British alike (analyses were run on the White British only and ethnic minority only samples separately and results are available on request). Taking both the 'racial identity' and Britishness identity effects together, this is highly suggestive that Englishness may be a racialised identity but that Britishness is not, consistent with a number of qualitative studies (Bechofer and McCrone 2015; Mann and Fenton 2017).

We now turn briefly to the effects of personality, although reiterate that we interpret these in subjective and identificational terms rather than reliable measures of personality traits. Neuroticism has no significant effect on support for leaving the EU; agreeableness and openness have significant effects on support for remaining in the EU; and conscientiousness and extraversion on support for leaving. These effects are largely consistent with those for left-right position as discussed earlier. To simplify, seeing oneself as kind and open to new experiences is associated with support for 'Remain', while seeing oneself as dutiful and sociable is associated with support for 'Leave'. While ensuring that our model of support for leaving the EU is more fully-specified, the findings here are not particularly unexpected, and we do not remark further here.

Of greater conceptual interest are the effects of personal network context, where we find that being a member of the higher volume, moderate diversity class is associated with stronger support for remaining in the EU than being a member of the lower volume, low diversity class. Being a member of the lower volume, higher diversity class is associated with no greater or lesser support for leaving the EU. This is of interest given the association between network diversity and tolerance (for example, Kaufmann and Harris 2015 regarding White tolerance); and between anti-immigrant attitudes and support for leaving the EU (Clarke et al 2017; Goodwin and Milazzo 2017). Further, the marginal effect for both is rather slight. While it is of course of interest that we find a difference at all, this suggests some moderation of the claims for the importance of social capital and network diversity, at least for this phenomenon. The identity-related variables appear to explain rather more of the variation in support for leaving the $\mathrm{EU}$, and our suspicion is that network volume plays the major role here rather than network diversity.

Looking at our final measures of connectedness, that for being a member of a civic organisation (rather than having no memberships) is associated with stronger support for remaining in the EU, intuitively consistent with the concept of connectedness as a resource and the less-resourced (on multiple dimensions of social resources) being more inclined to support leaving the EU. Finally, we have our indicator of neighbourhood attachment, which we treat as our measure of 'somewhereness'. Having a higher score on the neighbourhood attachment variable is associated with greater support for remaining in the EU, albeit at the borders of conventional levels of statistical significance $(p=0.099)$. Given that this challenges our prior assumption that a stronger neighbourhood attachment reflected locally-bound rather than metropolitan social identity and position, and access to local social resources, we report it as an important finding of interest (following McShane et al 2017) and worthy of further exploration. 


\section{Conclusion}

The result of the UK referendum on EU membership of 2016 has been assessed in terms of reaction to structural economic change, anti-immigrant feeling, nationalist sentiment towards the EU, anti-

establishment sentiment and cultural backlash. In this account, we highlight the social origins of support for leaving the $\mathrm{EU}$ and unpack identificational aspects of the vote. We provide an account more explicitly focused on ethnic and racial identity, particularly of the White British, as well as British national identity, for 'Leave' support, as well as the importance of network context and personality. Having stronger educational, political and professional identities promotes greater support for remaining in the EU, suggesting that these identities may serve as substitutes, at least with regard to EU attitudes. ${ }^{1}$

Popular and media accounts of support for Brexit have taken account of local pride in place and commitment to traditional, bonded communities: 'a vote for something more than money - for pride, belonging, community, identity, a sense of "home"' (Leadbeater 2016); and nostalgia for 'a lost, albeit mostly imaginary, era of secure, tightknit communities built around coal mines and manufacturing' (Higgins 2016). In this paper, we have demonstrated that traditional versus progressive social identities work do work in the direction hypothesised by such accounts, particularly via ethnic and racial identity; and further that there is evidence for a difference in personal network context consistent with a divide along these lines. Our next step will be to probe further the sources of identity; to provide a more explicitly causal account of social network context, by examining change in network context between waves 3 and 6; and to provide an account of the social, network and behavioural sources of identity. Our suspicion is that identity preferences and choices are located in relative status concerns, but this is far from established. The results in Table 3 focus attention on the identity-related variables rather more than the network-related variables. Our findings regarding social network diversity were less strong than expected. It is plausible that social advantage is associated with 'optimal diversity': a high volume of friendships which are diverse but not too much so that diversity inhibits the sharing of norms, though of course it is plausible that the pro-Remain effect indicated by Class 2 vs Class 1 membership is confounded by neighbourhood diversity and wealth. Membership of a civic association is associated with support for remaining in the EU rather than leaving, although the small size of the effect calls to mind Van Der Meer and Van Ingen's revisionist account of voluntary associations as 'not the schools of democracy they are proclaimed to be' (2009: 281).

We also note a number of caveats regarding our model. Our dependent variable is an attitudinal measure regarding a position regarding EU membership which is arguably abstract, particularly in advance of the referendum date, rather than a behavioural measure of intended or reported vote choice. It is conceivable that people do not vote in line with their attitudes, and we do not know how they were swayed by the campaigns in the run-up to the referendum. We do not take account of propensity to vote, and we do not differentiate those surveyed before the referendum (when the question was arguably more abstract) and those surveyed after (when the question was likely more salient). Importantly given our focus on ethnic and racial identity, we do not have explicit measures of Englishness, Scottishness and Welshness, so must be circumspect regarding how they differ in their effects from Britishness. The model is not explicitly causal, though we do note that many of the explanatory variables were drawn from earlier waves. In further analyses we could also take account of change in network type between Waves 3 and 6 . We do not take household or

\footnotetext{
${ }^{1}$ In fact, in separate analysis of the drivers of strong ethnic and racial identity, these identities appear complementary; moreover, it is noteworthy that reporting that ethnic and racial identity is important to who you are shows little structuring by occupational class or income.
} 
neighbourhood context explicitly into account. Our latent classes exhibit a fuzzy structure. Finally, as stated, we have no explicit measures of basic values, an important potential source of omitted variable bias.

Nevertheless, our findings add a fresh perspective to debate over the social origins of the Brexit result, much of which has revolved around economic disadvantage and 'left behind' accounts versus 'cultural backlash' accounts. We incorporate measures relatively-little used in political science and provide a more explicitly political sociological account of support for leaving the EU. While we favour the social identity theory account, and find that ethnocentrism provides a parsimonious account of the vote, we also argue for a reconciliation of identity and networks approaches. As Jenke and Huettel put it, identities are formed in social contexts (2017: 794). The distinction between identity and network approaches may be too sharp: relational sociologists argue that identity should be understood in terms of how stories create ties, with new social formations emerging as a result of new stories and connections. Both network relationships and identities are dynamic, and, in Oakeshottian vein, politics is a conversation. Identities and political values should accordingly be understood in terms of interaction as well as political resources; there is no necessary contradiction here. Further, connectedness can be conceived as having both behavioural and cognitive-affective elements: a behavioural connectedness via social network membership and active engagement; and 'imagined community' (after Anderson, 1983) via a sense of personal identity, of being connected to 'people like us'. This suggests a broader conceptualisation of identity in explicitly relational terms, with theoretical and substantive implications for research into drivers of the Brexit vote, and indeed broader questions relating to the current populist moment. 


\section{Bibliography}

Abrams, Samuel, Torben Iversen and David Soskice (2011), 'Informal Social Networks and Rational Voting', British Journal of Political Science, 41/2: 229-257.Adorno, Theodor W., Else Frenkel-Brunswik, Daniel Levinson and Nevitt Sanford, The Authoritarian Personality (New York: Harper \& Row).

Akerlof, George A. and Rachel E. Kranton (2000), 'Economics and identity', Quarterly Journal of Economics $115,715-753$

Alesina, Alberto and Eliana La Ferrara (2000), 'Participation in Heterogeneous Communities', Quarterly Journal of Economics, vol. 3: 847-904.

Allison, Paul D. (1999), 'Comparing Logit and Probit Coefficients Across Groups', Sociological Methods and Research, 28/2: 186-208.

Allport, Gordon W. (1954), The Nature of Prejudice (Reading, MA: Addison-Wesley).

Altemeyer, Bob (1996), The Authoritarian Specter (Cambridge, MA: Harvard University Press).

Anderson, Benedict (1983), Imagined Communities: Reflections on the Origin and Spread of Nationalism. New York and London: Verso.

Bakker, Bert and Claes de Vreese (2016), 'Personality and European Union attitudes: Relationships across European Union Attitude Dimensions', European Union Politics, vol. 17: 25-45.

Best, Henning and Christof Wolf, eds. (2014), The SAGE Handbook of Regression Analysis and Causal Inference (London: Sage).

Borgatti, Steve (2005), 'Centrality and Network Flow', Social Networks, vol. 27: 55-71.

Brady, Henry (1999), 'Political Participation', in J.P. Robinson, P.R. Shaver and L.S. Wrightsman, eds., Measures of Social Psychological Attitudes, Vol. 2: Measures of Political Attitudes (San Diego, CA: Academic Press), 737-801.

Carey, Sean (2002), 'Undivided Loyalties: Is National Identity an Obstacle to European Integration?', European Union Politics, 3/4: 387-413.

Clarke, Harold, Matthew Goodwin and Paul Whiteley (2017), 'Why Britain Voted for Brexit: An IndividualLevel Analysis of the 2016 Referendum Vote', Parliamentary Affairs.Coleman, James (1988), 'Social Capital in the Creation of Human Capital', American Journal of Sociology, vol. 94: 95-120.

Dilulio, John (2007), Godly Republic: A Centrist Blueprint for America's Faith-Based Future (Berkeley and Los Angeles: University of California Press).

Druckman, D. (1994), 'Nationalism, Patriotism, and Group Loyalty: A Social Psychological Perspective', Mershon International Studies Review, 38/1: 43-68.

Duckitt, John (1989), 'Authoritarianism and Group Identification: A New View of an Old Construct', Political Psychology, vol. 10:63-84.Durlauf, Steven and Marcel Fafchamps (2005), 'Social Capital', Handbook of Economic Growth, in Aghion, Philippe and Steven Durlauf (eds.), Handbook of Economic Growth, North Holland: Elsevier.

Van der Eijk, Cees, and Michael Marsh, 'Exploring the Irish vote on Lisbon', Trinity College Dublin Working Paper presented to the Elections, Public Opinion and Parties Group of the PSA, 2009. 
Evans, Geoff (1998), 'How Britain Views the EU', in Jowell. R., Curtice, J., Park, A., Brook, L., Thomson, K. and Bryson, C., eds. British - and European - Social Attitudes: The 15th Report: How Britain Differs (Aldershot: Ashgate).

Fieldhouse, Ed and David Cutts (2010), 'Immigration and Neighbourhood Diversity in the UK and US: Does Diversity Damage Social Capital?' in Tom Clark, Robert D. Putnam and Ed Fieldhouse (eds.), The Age of Obama: The Changing Place of Minorities in British and American Society (Manchester: Manchester University Press).

Ford, Rob and Matthew Goodwin (2014), Revolt on the Right: Explaining Support for the Radical Right in Britain (Abingdon: Routledge).

Gerber, Alan S., Gregory A. Huber, David Doherty, and Conor M. Dowling (2011), 'The Big Five Personality Traits in the Political Arena', Annual Review of Political Science, vol. 14: 265-287.

Glaeser, Edward L., David Laibson, and Bruce Sacerdote (2002), 'An Economic Approach to Social Capital', Economic Journal 112: F437-F458.

Goodhart, David (2017), The Road to Somewhere: The Populist Revolt and the Future of Politics (London: Hurst).

Goodwin, Matthew and Oliver Heath (2016), 'The 2016 Referendum, Brexit and the Left Behind: An Aggregate-level Analysis of the Result', Political Quarterly, 87/3: 323-332.

Goodwin, Matt and Caitlin Milazzo (2017), 'Taking Back Control?: Investigating the Role of Immigration in the 2016 Vote for Brexit', British Journal of Politics and International Relations.

Harris, John (2010), 'Griffin vs Hodge: the Battle for Barking', The Guardian, 13 March 2010, accessed online at https://www.theguardian.com/politics/2010/mar/13/nick-griffin-margaret-hodge-barking-dagenham, 01 September 2017.

Higgins, Andrew (2016), 'Wigan's Road to 'Brexit': Anger, Loss and Class Resentments', New York Times, 5 July 2016, https://www.nytimes.com/2016/07/06/world/europe/wigan-england-brexit-working-classvoters.html?mcubz=0, accessed online.

Hobolt, Sara (2016) 'The Brexit Vote: A Divided Nation, A Divided Continent', Journal of European Public Policy, 23/9: 1259-1277.

Hofferbert, Richard I. (1974), The Study of Public Policy (Indianapolis: Bobbs-Merrill).

Hooghe, Liesbet and Gary Marks (2005), 'Calculation, Community and Cues: Public Opinion on European Integration', European Union Politics, 6/4: 419-443.

Huckfeldt, Robert and John Sprague, Citizens, Politics, and Social Communication: Information and Influence in an Election Campaign (New York: Cambridge University Press, 1995).

Huddy, Leonie, Lilliana Mason and Lene Aarøe (2015), 'Expressive partisanship: campaign involvement, political emotion, and partisan identity', American Political Science Review, vol. 109: 1-17.

Inglehart, Ronald, and Pippa Norris (2016), 'Trump, Brexit, and the rise of Populism: Economic Have-Nots and Cultural Backlash', Faculty Research Working Paper Series, RWP16-026, University of Harvard, August 2016.

Jenke, Libby and Scott A. Huettel (2016), 'Issues or Identity? Cognitive Foundations of Voter Choice', Trends in Cognitive Sciences, 20/11: 794-804. 
Jennings, Will and Martin Lodge (2016), 'The Failures of Political Science: Trump, Brexit and beyond...', blog of the Division of Politics \& International Relations, University of Southampton,

https://sotonpolitics.org/2016/11/11/the-failures-of-political-science-trump-brexit-and-beyond/, accessed online 01 September 2017.

Johnson, Boris (2017), 'My Vision for a Bold, Thriving Britain Enabled by Brexit', Daily Telegraph, 15 September 2017, http://www.telegraph.co.uk/news/2017/09/15/boris-johnson-vision-bold-thriving-britainenabled-brexit/, accessed online 28 September 2017.

Johnston, Christopher, Howard G. Lavine, and Christopher M. Federico (2017), Open versus Closed: Personality, Identity, and the Politics of Redistribution (Cambridge: Cambridge University Press).

Kahan, Dan (2013), 'Ideology, Motivated Reasoning, and Cognitive Reflection', Judgment and Decision Making, 8/4: 407-424.

Kaufmann, Eric and Gareth Harris (2015), "'White Flight" or Positive Contact? Local Diversity and Attitudes to Immigration in Britain', Comparative Political Studies, 48/12: 1563-1590.

Kaufman, Eric (2016), 'It's NOT the economy, stupid: Brexit as a story of personal values', 7 July 2016, LSE British Politics and Policy blog, http://blogs.Ise.ac.uk/politicsandpolicy/personal-values-brexit-vote/, accessed online 01 September 2017.

Kaufman, Eric (2017), 'Racial Self-Interest is Not Racism: Ethno-Demographic Interests and the Immigration Debate', Policy Exchange, https://policyexchange.org.uk/wp-content/uploads/2017/03/Racial-Self-Interestis-not-Racism-FINAL.pdf, accessed 01 September 2017.

Lanza, Stephanie T., John J. Dziak, Liying Huang, Aaron T. Wagner and Linda M. Collins (2015), 'LCA Stata Plugin Users' Guide: Version 1.2', mimeo, Pennsylvania State University, https://methodology.psu.edu/downloads/lcastata, accessed 01 June 2017.

Laurence, James and Lee Bentley (2016), 'Does Ethnic Diversity Have a Negative Effect on Attitudes towards the Community? A Longitudinal Analysis of the Causal Claims within the Ethnic Diversity and Social Cohesion Debate', European Sociological Review, 32/1: 54-67.

Lazarsfeld, Paul, Bernard Berelson and Hazel Gauzet (1948), The People's Choice (New York: Columbia Unversity Press).

Lazer, David (2011), 'Networks in Political Science: Back to the Future', PS: Political Science \& Politics, 44/1: 61-68.

LCA Stata Plugin (Version 1.2) [Software]. (2015). University Park: The Methodology Center, Penn State. Retrieved from methodology.psu.edu, 01 June 2017.

Leadbeater, Charles (2016), 'The five ways the left can win back the Leavers', New Statesman and Society, 8 July 2016, https://www.newstatesman.com/politics/uk/2016/07/five-ways-left-can-win-back-leavers, accessed online 30 September 2016.

Letki, Natalia (2008), 'Does Diversity Erode Social Cohesion? Social Capital and Race in British Neighbourhoods', Political Studies, 56/1: 99-126.

Mann, Robin and Steve Fenton (2017), 'English National Identity, Resentment and the Leave Vote', Discover Society, 6 June 2017, Issue 45, http://discoversociety.org/2017/06/06/english-national-identity-resentmentand-the-leave-vote/, accessed online 01 September 2017. 
Marsden, Peter V. (2011), 'Survey Methods for Network Data', in John Scott and Peter J. Carrington, The SAGE Handbook of Social Network Analysis (London: Sage), 370-388.

McClurg, Scott D. (2003), 'Social Networks and Political Participation: The Role of Social Interaction in Explaining Political Participation', Political Research Quarterly, vol. 56: 449-64.

McCrae, Robert R. and Antonio Terracciano (2010), 'Universal Features of Personality Traits From the Observer's Perspective: Data From 50 Cultures', Journal of Personality and Social Psychology, 88/3: 547-561.

McCrae, Robert R. (2010), 'The Place of the FFM in Personality Psychology', Psychological Inquiry, 21: 57-64.

McCrone, David and Frank Bechhofer (2015), Understanding National Identity (Cambridge: Cambridge University Press).

McShane, Blakeley B., David Gal, Andrew Gelman, Christian Robert, and Jennifer L. Tackett (2017), 'Abandon Statistical Significance', mimeo, September 2017,

http://www.stat.columbia.edu/ gelman/research/unpublished/abandon.pdf, accessed 27 September 2017.

Morales, Laura and Alfonso Echazarra (2013), 'Will We All Hunker Down? The Impact of Immigration and Diversity on Local Communities in Spain', Journal of Elections, Public Opinion and Parties, vol. 23: 343-366.

Van Der Meer, Tom and Erik van Ingen (2009), 'Schools of Democracy? Disentangling the Relationship between Civic Participation and Political Action in 17 European Countries', European Journal of Political Research, vol. 48: 281-308, doi: 10.1111/j.1475-6765.2008.00836.x

Mische, Ann (2011), 'Relational Sociology, Culture, and Agency', in John Scott and Peter Carrington (eds.), The SAGE Handbook of Social Network Analysis (London: Sage), 80-97.

Mondak, Jeffery J., Matthew V. Hibbing, Damarys Canache, Mitchell A. Seligson, and Mary R. Anderson (2010), 'Personality and Civic Engagement: An Integrative Framework for the Study of Trait Effects on Political Behavior', American Political Science Review, vol: 104 (February): 85-110.

Mood, Carina (2010), 'Logistic Regression: Why We Cannot Do What We Think We Can Do, and What We Can Do About It', European Sociological Review, 26/1: 67-82, https://doi.org/10.1093/esr/jcp006

Nicoll Victor, Jennifer, Alexander H. Montgomery, and Mark Lubell, eds. (2017), The Oxford Handbook of Political Networks (Oxford: Oxford University Press).

Pichler, Florian and Claire Wallace (2009), 'Social Capital and Social Class in Europe: The Role of Social Networks in Social Stratification', European Sociological Review, 25/3: 319-332, https://doi.org/10.1093/esr/jcn050

Putnam, Robert D. (2000), Bowling Alone: The Collapse and Revival of American Community (New York: Simon and Schuster).

Putnam, Robert D. and David Campbell (2010), American Grace: How Religion Divides and Unites Us (New York: Simon and Schuster).

Robinson, David (2010), 'New Immigrants and Migrants in Social Housing in Britain: Discursive Themes and Lived Realities', Policy and Politics, 38/1: 57-77.

Schoen, Harald and Siegfried Schumann (2007), 'Personality Traits, Partisan Attitudes, and Voting Behavior. Evidence from Germany', Political Psychology, 28: 471-498. 
Storm, Ingrid (2011), "'Christian Nations"? Ethnic Christianity and Anti-Immigration Attitudes in Four Western European Countries', Nordic Journal of Religion and Society, 24/1: 75-96.

Storm, Ingrid (2015), 'Civic Engagement in Britain: The Role of Religion and Inclusive Values', European Sociological Review, vol: 31/1: 14-29, https://doi.org/10.1093/esr/jcu077

Sturgis, Patrick, lan Brunton-Smith, Sanna Read and Nick Allum (2011), 'Does Ethnic Diversity Erode Trust? Putnam's 'Hunkering Down' Thesis Reconsidered', British Journal of Political Science, vol. 41: 57-82.

Tajfel, Henri E. (1978), Differentiation between Social Groups: Studies in the Social Psychology of Intergroup Relations, Academic Press.

Tajfel, Henri and Turner, John (1979), 'An integrative theory of intergroup conflict', in W. G. Austin, \& S. Worchel (eds.), The social psychology of intergroup relations (Monterey, CA: Brooks/Cole), 33-37.

University of Essex. Institute for Social and Economic Research, NatCen Social Research, Kantar Public. (2016). Understanding Society: Waves 1-6, 2009-2015. [data collection]. 8th Edition. UK Data Service. SN: 6614, http://doi.org/10.5255/UKDA-SN-6614-9

University of Essex. Institute for Social and Economic Research, NatCen Social Research. (2017). Understanding Society: Wave 8, 2016. [data collection]. Early Access Edition.

Vaisey, Stephen and Omar Lizardo (2010), 'Can Cultural Worldviews Influence Network Composition?', Social Forces, 88/4: 1595-1618.

Wilson, John (2000), 'Volunteering', Annual Review of Sociology, vol. 26: 215-240.

Zuckerman, Alan, Nicholas A. Valentino, and Ezra W. Zuckerman (1994), 'A Structural Theory of Vote Choice: Social and Political Networks and Electoral Flows in Britain and the United States', Journal of Politics, 56/4: 1008-1033. 
Appendix

\section{A1. Descriptive Statistics}

\begin{tabular}{|c|c|c|c|}
\hline Variable & $\begin{array}{l}\text { Mean (standard } \\
\text { deviation) or } \\
\text { percentage (\%) }\end{array}$ & Base N (unweighted) & $\begin{array}{l}\text { Missingness } \\
\text { (\%) }\end{array}$ \\
\hline Male & 47.4 & 18,729 & \multirow[t]{2}{*}{$<0.1$} \\
\hline Female & 52.6 & 18,279 & \\
\hline Holds degree & 23.7 & 18,669 & \multirow[t]{2}{*}{0.3} \\
\hline No degree & 76.3 & 18,669 & \\
\hline Pre-war generation & 16.4 & 18,720 & \multirow[t]{4}{*}{0.1} \\
\hline Baby boom generation & 37.2 & 18,720 & \\
\hline Generation X & 22.0 & 18,720 & \\
\hline Generation Y & 24.5 & 18,720 & \\
\hline $\begin{array}{l}\text { Professional or managerial } \\
\text { occupation }\end{array}$ & 33.2 & 18,728 & \multirow[t]{8}{*}{$<0.1$} \\
\hline Intermediate occupation & 11.8 & 18,728 & \\
\hline $\begin{array}{l}\text { Self-employed, small business } \\
\text { owners }\end{array}$ & 7.8 & 18,728 & \\
\hline Semi-routine occupation & 22.2 & 18,728 & \\
\hline Routine occupation & 10.0 & 18,728 & \\
\hline Retired & 8.3 & 18,728 & \\
\hline Student & 3.0 & 18,728 & \\
\hline Other (outside labour market) & 3.8 & 18,728 & \\
\hline White British & 88.5 & 18,417 & \multirow[t]{6}{*}{1.7} \\
\hline White Other & 4.4 & 18,417 & \\
\hline Mixed ethnicity & 1.2 & 18,417 & \\
\hline Asian & 4.0 & 18,417 & \\
\hline Black & 1.4 & 18,417 & \\
\hline Other ethnicity & 0.4 & 18,417 & \\
\hline Owner-occupier & 36.8 & 18,514 & \multirow[t]{4}{*}{1.2} \\
\hline Mortgage-holder & 35.9 & 18,514 & \\
\hline Social renter & 15.6 & 18,514 & \\
\hline Private renter & 11.7 & 18,514 & \\
\hline No religious affiliation & 48.6 & 16,651 & \multirow[t]{6}{*}{11.1} \\
\hline Anglican & 24.8 & 16,651 & \\
\hline Catholic & 7.8 & 16,651 & \\
\hline Other Christian & 11.2 & 16,651 & \\
\hline Other Religion & 5.4 & 16,651 & \\
\hline $\begin{array}{l}\text { Reports having religious } \\
\text { affiliation but coded } \\
\text { 'inapplicable' }\end{array}$ & 2.2 & 16,651 & \\
\hline $\begin{array}{l}\text { Never attends a place of } \\
\text { worship }\end{array}$ & 12.2 & 16,648 & 11.1 \\
\hline
\end{tabular}




\begin{tabular}{|c|c|c|c|}
\hline $\begin{array}{l}\text { Attends a place of worship } \\
\text { less frequently }\end{array}$ & 67.4 & 16,648 & \multirow{4}{*}{1.0} \\
\hline Attends at least weekly & 20.4 & 16,648 & \\
\hline Lowest income quintile group & 15.2 & 18,543 & \\
\hline Second income quintile group & 18.8 & 18,543 & \\
\hline $\begin{array}{l}\text { Base: Middle income quintile } \\
\text { group }\end{array}$ & 20.9 & 18,543 & \\
\hline Fourth income quintile group & 20.9 & 18,543 & \\
\hline Highest income quintile group & 24.2 & 18,543 & 1.0 \\
\hline $\begin{array}{l}\text { Base: resident in England and } \\
\text { Wales }\end{array}$ & 91.8 & 18,543 & \multirow[t]{2}{*}{1.0} \\
\hline Resident in Scotland & 8.2 & 18,543 & \\
\hline $\begin{array}{l}\text { Race/ethnicity very/fairly } \\
\text { important }\end{array}$ & 39.1 & 18,088 & \multirow[t]{2}{*}{3.4} \\
\hline $\begin{array}{l}\text { Race/ethnicity not very/not } \\
\text { at all important }\end{array}$ & 60.3 & 18,088 & \\
\hline $\begin{array}{l}\text { Profession very/fairly } \\
\text { important }\end{array}$ & 58.6 & 18,100 & \multirow[t]{2}{*}{3.4} \\
\hline $\begin{array}{l}\text { Profession not very/not at all } \\
\text { important }\end{array}$ & 41.4 & 18,100 & \\
\hline $\begin{array}{l}\text { Education very/fairly } \\
\text { important }\end{array}$ & 63.2 & 18,095 & \multirow[t]{2}{*}{3.4} \\
\hline $\begin{array}{l}\text { Education not very/not at all } \\
\text { important }\end{array}$ & 36.8 & 18,095 & \\
\hline Age very/fairly important & 70.5 & 18,096 & \multirow[t]{2}{*}{3.4} \\
\hline $\begin{array}{l}\text { Age not very/not at all } \\
\text { important }\end{array}$ & 29.5 & 18,096 & \\
\hline Politics very/fairly important & 37.7 & 18,086 & \multirow[t]{2}{*}{3.4} \\
\hline $\begin{array}{l}\text { Politics not very/not at all } \\
\text { important }\end{array}$ & 62.3 & 18,086 & \\
\hline Gender very/fairly important & 62.2 & 18,092 & \multirow[t]{2}{*}{3.4} \\
\hline $\begin{array}{l}\text { Gender not very/not at all } \\
\text { important }\end{array}$ & 37.8 & 18,092 & \\
\hline Family very/fairly important & 91.9 & 18,110 & \multirow[t]{2}{*}{3.3} \\
\hline $\begin{array}{l}\text { Family not very/not at all } \\
\text { important }\end{array}$ & 8.1 & 18,110 & \\
\hline $\begin{array}{l}\text { Britishness important (scores } \\
6+\text { out of } 10 \text { ) }\end{array}$ & 73.3 & 17,701 & \multirow[t]{2}{*}{5.5} \\
\hline $\begin{array}{l}\text { Britishness not important (0-5 } \\
\text { out of 10) }\end{array}$ & 26.8 & 17,701 & \\
\hline Neuroticism & $3.6(1.4)$ & 14,789 & 21.0 \\
\hline Agreeableness & $5.6(1.0)$ & 14,789 & 21.0 \\
\hline Openness & $4.6(1.3)$ & 14,749 & 21.3 \\
\hline Conscientiousness & $5.4(1.1)$ & 14,794 & 21.0 \\
\hline Extraversion & $4.6(1.3)$ & 14,794 & 21.0 \\
\hline $\begin{array}{l}\text { Low volume, low diversity } \\
\text { network }\end{array}$ & 39.5 & 16,395 & 12.5 \\
\hline
\end{tabular}




\begin{tabular}{|l|l|l|l|}
\hline $\begin{array}{l}\text { High volume, moderate } \\
\text { diversity }\end{array}$ & 36.9 & 16,395 & \\
\hline Low volume, high diversity & 23.5 & 16,395 & 2.0 \\
\hline $\begin{array}{l}\text { Member of a civic } \\
\text { organisation }\end{array}$ & 55.1 & 18,363 & \\
\hline $\begin{array}{l}\text { Not a member of a civic } \\
\text { organisation }\end{array}$ & 44.9 & 18,363 & 5.7 \\
\hline $\begin{array}{l}\text { Neighbourhood attachment } \\
\text { Supports leaving the }\end{array}$ & $-0.008(0.945)$ & 17,662 & 4.5 \\
\hline European Union & 45.2 & 17,896 & \\
\hline
\end{tabular}

Table A1: Descriptive Statistics, Understanding Society, Wave 8 early release sample. Personality variables drawn from Wave 3 responses; religious variables drawn from Wave 4; organisational membership, network volume/diversity and neighbourhood attachment variables drawn from Wave 6 responses.

\section{A2. Latent Class Analysis}

The following variables were treated as manifest variables when the latent class analysis was conducted: the reported proportion of friends of a similar age, of a similar race, of a similar level of education, in work, of a similar level of income, living in the same area, who were also family members, and the number of close friends. The model failed to converge when the latter item was included as a count (including when trimmed at 30) and so we converted the measure to quartile groups. For this analysis, a three-class model was selected, identifying three latent subgroups characterised as 'low volume, low diversity'; 'high volume, moderate diversity'; and 'low volume, high diversity'. Table A2 below summarises a variety of fit statistics by number of classes.

\begin{tabular}{lllllll}
\hline $\begin{array}{l}\text { Number } \\
\text { of } \\
\text { classes }\end{array}$ & Log-likelihood & AIC & BIC & Entropy & $\begin{array}{l}\text { Number of } \boldsymbol{y} \\
\text { parameters }\end{array}$ & $\begin{array}{l}\text { Number of } \boldsymbol{\rho} \\
\text { parameters }\end{array}$ \\
\hline 1 & -374345.5 & 76016.9 & 76238.7 & 1.00 & 0 & 26 \\
2 & -365552.6 & 58484.9 & 58937.0 & 0.60 & 1 & 52 \\
3 & -363253.9 & 53941.5 & 54624.0 & 0.54 & 2 & 78 \\
4 & -362486.3 & 52460.4 & 53373.2 & 0.51 & 3 & 104 \\
5 & -361843.1 & 51228.0 & 52371.1 & 0.50 & 4 & 130 \\
6 & -361450.0 & 50495.8 & 51869.3 & 0.49 & 5 & 156 \\
7 & -361135.8 & 49921.4 & 51525.2 & 0.49 & 6 & 182 \\
8 & -360926.3 & 49556.4 & 51390.6 & 0.48 & 7 & 208 \\
\hline
\end{tabular}

Table A2: Model fit indices for latent class analysis models. 


\begin{tabular}{|c|c|c|c|}
\hline & Class 1 & Class 2 & Class 3 \\
\hline $\begin{array}{l}\text { Probability of class } \\
\text { membership }\end{array}$ & 39.5 & 36.9 & 23.5 \\
\hline $\begin{array}{l}\text { Friends are of similar age: } \\
\text { more than half }\end{array}$ & 43.7 & 45.0 & 11.3 \\
\hline $\begin{array}{l}\text { Friends are of similar age: } \\
\text { half or less }\end{array}$ & 24.3 & 19.1 & 56.6 \\
\hline $\begin{array}{l}\text { Friends are of same race: } \\
\text { more than half }\end{array}$ & 41.4 & 41.3 & 17.3 \\
\hline $\begin{array}{l}\text { Friends are of same race: } \\
\text { half or less }\end{array}$ & 16.9 & 14.3 & 68.9 \\
\hline $\begin{array}{l}\text { Friends are of similar level of } \\
\text { education: more than half }\end{array}$ & 46.2 & 47.1 & 6.8 \\
\hline $\begin{array}{l}\text { Friends are of similar level of } \\
\text { education: half or less }\end{array}$ & 11.7 & 10.0 & 78.3 \\
\hline $\begin{array}{l}\text { Friends have a job: more } \\
\text { than half }\end{array}$ & 29.7 & 45.3 & 25.0 \\
\hline $\begin{array}{l}\text { Friends have a job: half or } \\
\text { less }\end{array}$ & 51.0 & 26.4 & 22.6 \\
\hline $\begin{array}{l}\text { Friends have similar income: } \\
\text { more than half }\end{array}$ & 46.3 & 48.1 & 5.6 \\
\hline $\begin{array}{l}\text { Friends have similar income: } \\
\text { half or less }\end{array}$ & 26.3 & 32.0 & 41.7 \\
\hline $\begin{array}{l}\text { Friends living in same local } \\
\text { area: more than half }\end{array}$ & 50.7 & 36.2 & 13.1 \\
\hline $\begin{array}{l}\text { Friends living in same local } \\
\text { area: half or less }\end{array}$ & 26.9 & 41.8 & 31.3 \\
\hline $\begin{array}{l}\text { Friends also family members: } \\
\text { more than half }\end{array}$ & 54.9 & 25.7 & 19.4 \\
\hline $\begin{array}{l}\text { Friends also family members: } \\
\text { half or less }\end{array}$ & 33.3 & 43.5 & 23.2 \\
\hline $\begin{array}{l}\text { Lowest quartile group of } \\
\text { number of close friendships }\end{array}$ & 55.0 & 16.8 & 28.2 \\
\hline Second quartile group & 39.7 & 33.8 & 26.5 \\
\hline Third quartile group & 32.9 & 43.3 & 23.8 \\
\hline $\begin{array}{l}\text { Highest quartile group of } \\
\text { number of friendships }\end{array}$ & 31.3 & 49.8 & 18.9 \\
\hline
\end{tabular}

Table A3: Probability of latent class membership and item-response probabilities within each class.

\begin{tabular}{llll}
\hline & Class 1 & Class 2 & Class 3 \\
\hline $\begin{array}{l}\text { Pre-war generation } \\
\text { Baby Boom }\end{array}$ & 62.5 & 24.1 & 13.5 \\
generation & 40.4 & 36.7 & 22.9 \\
$\begin{array}{l}\text { Generation X } \\
\text { Generation Y }\end{array}$ & 29.6 & 42.4 & 28.0 \\
$\begin{array}{l}\text { Lowest income } \\
\text { quintile group }\end{array}$ & 30.0 & 42.0 & 28.1 \\
$\begin{array}{l}\text { Highest income } \\
\text { quintile group }\end{array}$ & 28.9 & 23.3 & 23.8 \\
Support for leaving EU & 43.9 & 47.4 & 23.9 \\
\hline
\end{tabular}

Table A4: Social generation, income group and support for leaving the EU by latent class membership. 


\section{A3. Factor Analysis}

The Cronbach's alpha for the seven indicators of neighbourhood attachment drawn from Wave 6 was 0.83 , which suggests a single scale has good internal consistency.

The Kaiser-Meyer-Olin measure of sampling adequacy was 0.90 , above the recommended value of 0.6 ; Bartlett's test of sphericity was significant $\left(\chi^{2}(28)=1.25 e+05, p<0.001\right)$.

A three-factor solution was identified, but the second accounted for 3.6 and the third 1.1 per cent of the variance, which was trivial. Further, none of the factor loadings for the individual items for the second and third factors were above $|0.3|$ suggesting weak factorial structure. Figure $X$ below summarises the factor loadings for each.

\section{Factor 1 Factor 2 Factor 3}

\begin{tabular}{lrrr} 
Belongs to neighbourhood & 0.750 & -0.119 & -0.115 \\
Local friends mean a lot & 0.789 & 0.093 & -0.152 \\
Advice obtainable locally & 0.752 & 0.226 & -0.065 \\
Can borrow things from neighbours & 0.599 & 0.274 & 0.105 \\
Willing to improve neighbourhood & 0.545 & 0.062 & 0.161 \\
Plan to stay in neighbourhood & 0.628 & -0.281 & 0.045 \\
Am similar to others in neighbourhood & 0.713 & -0.234 & 0.044 \\
Talk regularly to neighbours & 0.727 & -0.012 & 0.061 \\
\hline Variance accounted for (\%) & 47.9 & 3.6 & 1.1 \\
\hline
\end{tabular}

Table A5: Factor loadings of variables by factor analysis (extraction method: common factor analysis). 